\title{
Managerial Performance Model of Private Higher Education in The South Sumatra
}

\author{
Anuar Sanusi \\ Faculty of Economics and Business Informatics and \\ Business Institute Darmajaya Bandar Lampung \\ anuarsanusi@ymail.com
}

\begin{abstract}
This paper tries to assess the application of quantitative approaches and hypothesis testing using 'Path Analysis' technique as an alternative approach to the performance of managerial leadership that can be used to achieve the goals in finding and determine the factors that influence and support the managerial performance leadership. Analysis of the data that is used in this study consisted of descriptive analysis to look at the characteristics of the population which is netted in the study and path analysis. The sample of technique in this study is using proportionate stratified random sampling technique. The number of samples, which is used as the respondent in the unit of analysis of this study, is $\mathbf{1 3 0}$ head of private universities around Kopertis region II, southern Sumatran. The results of data analysis show that (1) the leadership of a significant and positive impact on managerial performance, (2) empowerment of human resources directly affects on managerial performance, (3) governance directly affects managerial performance, (4) the leadership of a significant and positive impact on governance, (5) directly affects the organizational culture of good governance, (6) human resources empowerment significant and positive impact on governance.

Key Words: leadership, organizational culture, empowerment, good governance and managerial performance
\end{abstract}

\section{INTRODUCTION}

Globalization era was characterized by various changes in the aspects of life, as the impact of human resource development (HRD). It is one of the important and strategic keywords. One of the strategic Private College was to support the availability of human resources (HR) professionals is education, particularly through higher education.

Increasing the managerial performance will improve and encourage stakeholders (leadership, faculty, support staff and students) in developing performance with full motivation, effectively, efficiently and productively. Competition among educational institutions are increasingly caught up in materialists such as building, number of airconditioned rooms, and number of new students to be the standard of managerial performance success of a University. Another standard of college managerial performance success as suggested by Stoop (1996) in Wibisono (2006) that besides of financial variables (financial), more non-financial variables (nonfinancial) such as human resource development variable for the college.

This situation can be indicated by: (1) Unsupported Managerial performance by organization performance (2)

\author{
Linda Septarina \\ Faculty of Computer Science Informatics and Business \\ Insitute Darmajaya Bandar Lampung \\ lindaseptarinaeff@yahoo.com
}

Management role, (3) employee competence (4) University's practices of governance (good University governance) in University (5) Higher Education Bureaucracy and leaderships well as accountability that only the boss (single accountability) in the central government and not to the stakeholders and 6) the enormous amounts of authority DIKTI (2004). Optimizing the performance of managerial is the duty of the management to look it as related and influenced elements. Some of predicted factors related to support managerial performance are leadership, organizational culture, human resource development and governance of high education.

Predominantly, universities are projected to be managed professionally by endorsing the principles of good university governance as well as ensuring quality of service, particularly for students, faculty and staffs or internal stakeholders. In building good governance throughout compliance and commitment, University should have a strong leadership to influence individuals and groups in achieving goals. Empowerment of effective governance on study program will be able to empower Human Resources managerial system effectively. Orientation of human resource development is directed to in line with the principle of university management according to GUG which reflects to the Indonesia laws and regulations.

Strong organizational culture will create a conformity inherent in a system and accommodate the values, norms, structures, roles, functions and aspirations through a study program stakeholders that shows reflection of governance university implementation. Two of managerial performances were adopted from modern University management quality are variable quality of leadership skills and active participation of employees Spanbauer (1992).

\section{Related Works \\ Managerial Performance}

Wanger states that managerial performance is a system of work outcomes measurements along with efficiency measurement of the implementation of a program or a service by an organization, which is carried out systematically with proper procedure. Information obtained is used to increase the effectiveness and efficiency of programs and service provisions. Thus the Managerial Performance covers all aspects, beginning from performance measurement up to performance information usage, which is produced for decision making, resource allocation and improved service provision. $^{2}$ 
together in a society together. Empowerment Model (Empowerment) is Sharafat Khan, among others; 1) Desire, 2) Trust, 3) Confidence, 4) Credebility, 5) Accountability, and 6) Communication.

\section{Good Governance}

Governance is a behavior, a way or method used by a company to optimally utilize the full potential and elements owned in order to achieve the vision and mission that has been set. Technically good governances expressed as a systematic effort in a process to achieve the goals of the organization, through the functions of planning, execution, control, and increase follow-up.

Moreover, besides covering all of the elements and process above, good governance also has a key aim to continually increase the quality of the company in order to achieve the vision and mission which has been set. Key Elements of good Governance, One of which can be considered suitable for the company, is a formulation made by Sutiono (2004) on the characteristics of good governance, which is modified as follows; transparency, organization, participation, responsiveness, efficiency and effectiveness, accountability, leadership. While there are 10 principals according to the UNDP Good Governance; (1) Law Enforcement, (2) Transparency, 3) Equality, 4) Responsiveness, (5) Forward Insights, (6) Accountability, (7) Supervision, (8) Efficiency, (9) Effectiveness, and 10) Professionalism. While the scope of Governance in the PT in general includes elements; planning, execution, control, and continuous quality improvement.

\section{Research Hypothesis.}

The hypothesis proposed in this research are: 1) there is a direct leadership influence on managerial performance; 2) there is a direct leadership influence on governance; and there is no direct influence on the performance of managerial leadership through good governance; 3) there is a direct influence of organizational culture on governance; and there is no direct influence of organizational culture on managerial performance by good governance; 4) there is a direct influence on the governance empowerment; and there is no direct influence on the performance of managerial empowerment through governance; 5) there is a direct influence on the performance of managerial empowerment; 6) there is a direct influence on the performance of managerial governance; 7) there is a significant relationship between leadership and organizational culture, 8) there is a significant relationship between leadership with empowerment and 9) there is a significant relationship between culture based organizations and empowerment.

\section{METHODOLOGY RESEARCH}

\section{Research Methods.}

The method used in this study are; Causal method with observation, interview, questionnaire. The method used in this study is a survey of explanation (explanatory survey method). Observation is conduct by direct observations to several sections and universities there and see at first hand empowerment that can be developed within an organization to ensure the success of the process of empowerment 
who served the section at the Private Higher Education in Kopertis region II Sumabagsel.

The unit of analysis of this research is a private university in southern Sumatra which is incorporated in Kopertis Region II Palembang as many as 130 Colleges (PRIVATE COLLLAGE). The data used in this data were primary data, and the data collection techniques were through interviews, observations, and questionnaires.

\section{Research Objective:}

- To explain the impact of leadership, organization culture, and utilization of managerial performance.

- To determine how big the direct impact of leadership towards managerial performance. $\square$ To determine how big the direct impact of leadership towards good governance; and to determine how big the indirect influence of leadership towards managerial performance

- To determine how big the direct impact of organization culture towards good governance; and the indirect effect of organization culture towards managerial performance through good governance.

- To determine how big the direct impact of human resource empowerment towards good governance; and the indirect effect of empowerment of human resources towards managerial performance through governance.

- To determine how big the direct impact of the empowerment of human resources towards managerial performance.

- To determine how big the direct impact of governance towards managerial performance is.

- To determine how big the direct impact is simultaneously between leadership, organization culture, and empowerment of human resources towards governance.

\section{Population and Sample}

The population for this research were all the leaders of private higher education institutions in Kopertis Region II, South of Sumatera. Samples in this research were taken using Stratified random sampling technique, and the technique used to obtain 130 samples form a population of 195 respondents, the formula or Isaac \& Michale (1981:192) in Sukardi (2004:55) model were used.

\section{RESULT AND DISCUSSION}

\section{Model test}

A causal model was formed theoretically from the flow in the following diagram. Standardized solution

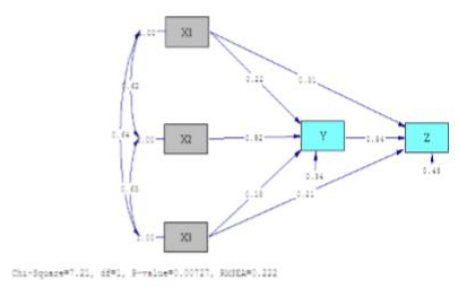

\section{T-VALUES}

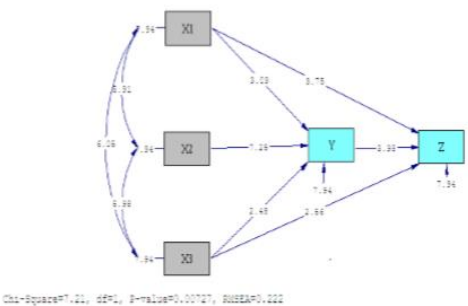

The model above shows that the coefficient of the analysis flow result were: (1) substructure of the first model, the line between $\mathrm{x} 1, \mathrm{x} 2, \mathrm{x} 3$ towards $\mathrm{y}$, and (2) substructure on model two lines between $\mathrm{x} 1, \mathrm{x} 2, \mathrm{x}$, and $\mathrm{y}$ towards $\mathrm{z}$ after trimming was done.

\section{Structure 1 Model:}

The model equation forms sub-structure model 1, is said to be highly significant with the equation as follow: $\mathrm{Y}=19.81$ $+0.22 * \mathrm{X} 1+0.52 * \mathrm{X} 2+0.18 * \mathrm{X} 3$, errorvar. $=0.34, \mathrm{Ry}=0.66$

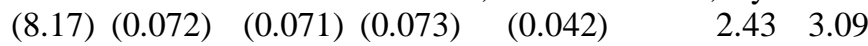
$\begin{array}{llll}7.25 & 2.48 & 7.94 & \text { Individual Testing of Coefficient The }\end{array}$ affect of leadership (x1) towards Good Governance (Y) (Y) $\mathrm{t}$-count $=3.09$ and $\mathrm{t}$-table $=1,960$

\section{First Hypothesis.}

The path coefficient is significant if $\mathrm{t}$-count $>\mathrm{t}$-table. The calculation results from $t$ test were $t$-count $=3.09$, whereas $t$ table $=1,96$ at $\mathrm{dk}=128$ and $\alpha=0,05$, therefore $\mathrm{t}$-count $>\mathrm{t}-$ table or $3.09>1,96$. This shows that the impact of leadership (X1) towards Governance (Y) was highly significant.

This case shows that the influence of leadership (X1) towards system of performance $(\mathrm{Y})$ is really significant. So that, it can be counted t-count $>$ t-table means that $\mathrm{H} 0$ rejected and $\mathrm{H} 1$ accepted. It means that the hypothesis given, is can be found the leadership influence X1) towards the system of performance (Y).

\section{Second Hypothesis.}

Through the path coefficient test of significance and organization culture (X2) towards Good Governance (Y) managerial performance $(\mathrm{Z})$, therefore the test of significance was done by using $t$ test. This test is called the trimming theory. Path coefficient is significant if value $\mathrm{t}$-count $>\mathrm{t}$ table. Results of the $t$ test calculations were $t$-count $=7.25$, whereas table $=1,960$ at $\mathrm{dk}=128$ and $\alpha=0,05$, therefore $\mathrm{t}$ count $>$ t-table or $7.25>1,960$. This shows that the impact of leadership (X1) towards good governance (Y) was highly significant. Which means that t-count $>$ t-table, H0 was denied and H1 was accepted. The proposed hypothesis, there is an impact of organization culture (X2) towards good governance $(\mathrm{Y})$. 


\section{Third Hypothesis}

Through the path coefficient test of significance and empowerment of human resources (X3) towards Good Governance (Y) which was tested using the t-test called the trimming theory. Path coefficient is significant if $\mathrm{t}$-count $>\mathrm{t}$ table. Results from the t-test were t-count $=2.48$, whereas $\mathrm{t}$ table $=1,960$ at $\mathrm{dk}=128$ and $\alpha=0,05$, therefore $\mathrm{t}$-count $>\mathrm{t}$ table or $2.48>1,96$. This result shows that the impact of empowerment of human resources (X3) towards Good Governance (Y) was highly significant. Therefore, t-count > t-table which means that $\mathrm{H} 0 \mathrm{~d}$ as denied and $\mathrm{H} 1$ accepted. This also means that the proposed hypothesis was that there is an impact of empowerment of human resources(X3) towards Good Governance (Y).

\section{Structure 2 Model:}

The path significance result of the coefficient test as a whole is the structural equation model $2: \mathrm{Z}=28.10+0.34 * \mathrm{Y}+$ $0.31 * \mathrm{X} 1+0.21 * \mathrm{X} 3$, errorvar. $=0.43, \mathrm{Ry}=0.57(9.29)$

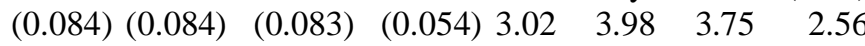
7.94

\section{Fourth Hypothesis}

The results of the test of significance path coefficient and good governance $(\mathrm{Y})$ towards managerial performance $(\mathrm{Z})$, the t-test was performed. This test is called the trimming theory. The path coefficient is significant of t-count $>t$-table. The calculation results of the t-test were $\mathrm{t}$-count $=3.98$, whereas t-table $=1,960$ at $\mathrm{dk}=128$ and $\alpha=0,05$, therefore $\mathrm{t}$ count $>$ t-table or $3.98>1,960$. This result shows that the impact of good governance (Y) towards managerial performance (Z) was highly significant. This means that $\mathrm{t}$ count $>\mathrm{t}$-table so that $\mathrm{H} 0$ was denied and $\mathrm{H} 1$ accepted. The proposed hypothesis is that there is an impact of good governance $(Y)$ towards managerial performance $(\mathrm{Z})$.

\section{Fifth Hypothesis}

Leadership has a highly significant positive impact towards managerial performance was obtained from the test of significance path coefficient and leadership (X1) towards managerial performance $(\mathrm{Z})$, after the t-test was performed using the trimming theory. The coefficient past is significant if $\mathrm{t}$-count $>\mathrm{t}$-table. The calculation results of the t-test were $\mathrm{t}$-count $=3.75$ whereas $\mathrm{t}$-table $=1.960$ at $\mathrm{dk}=128$ and $\alpha=$ 0.05 , so that $\mathrm{t}$-count $>\mathrm{t}$-table or $2.48>1,960$. This result shows that the impact of leadership (X1) towards managerial performance $(Z)$ was highly significant, in which $t$-count $>t$ table and that $\mathrm{H} 0$ is denied and $\mathrm{H} 1$ is accepted. The proposed hypothesis is that there is an impact of leadership (X1) towards managerial performance (Z). Sixth Hypothesis To perform the test of significance path coefficient and empowerment of human resources (X3) towards managerial performance $(Z)$, therefore the t-test was performed, this test was called the trimming theory. The coefficient past is significant if $\mathrm{t}$-count $>\mathrm{t}$-table. The calculation results of the $\mathrm{t}$-test were $\mathrm{t}$-count $=2.56$ whereas $\mathrm{t}$-table $=1.96$ at $\mathrm{dk}=128$ and $\alpha=0.05$, so that $\mathrm{t}$-count $>\mathrm{t}$-table or $2.56>1,96$. This result shows that the impact of empowerment of human resources (X3) towards managerial performance (Z) was highly significant, in which t-count $>\mathrm{t}$-table and that $\mathrm{HO}$ is denied and H1 is accepted. The proposed hypothesis is that there is an impact empowerment of human resources (X3) towards managerial performance $(\mathrm{Z})$.

Table 1. Data Recapitulation of the Hypothesis Testing Results

\begin{tabular}{|c|c|c|c|c|}
\hline No & Hypothesis & t-count & t-table & Description \\
\hline 1 & $\begin{array}{l}\text { Hypothesis-1: The } \\
\text { impact of leadership (x1) } \\
\text { towards good governance } \\
(\mathrm{Y})\end{array}$ & 3.09 & 1.96 & Significant \\
\hline 2 & $\begin{array}{l}\text { Hypothesis-2: The } \\
\text { impact of organizational } \\
\text { value }(x 2) \text { towards good } \\
\text { governance }(Y)\end{array}$ & 7.25 & 1.96 & Significant \\
\hline 3 & $\begin{array}{l}\text { Hypothesis-3: The } \\
\text { impact of empowerment } \\
\text { (X3) towards good } \\
\text { governance (Y) }\end{array}$ & 2.48 & 1.96 & Significant \\
\hline 4 & $\begin{array}{l}\text { Hypóthesis-4: } \\
\text { impact of } \text { The } \\
\text { governance(Y) towards } \\
\text { managerial performance } \\
(\mathrm{Z})\end{array}$ & 3.98 & 1.96 & Significant \\
\hline 5 & $\begin{array}{l}\text { Hypóthesis-5: The } \\
\text { impact of leadership (X1) } \\
\text { towards managerial } \\
\text { performance }(\mathrm{Z})\end{array}$ & 3.75 & 1.96 & Significant \\
\hline 6 & $\begin{array}{l}\text { Hypothesis-6: The } \\
\text { impact of empowerment } \\
\text { (X3) towards managerial } \\
\text { performance }(\mathrm{Z})\end{array}$ & 2.56 & 1.96 & Significant \\
\hline
\end{tabular}

\section{Direct Impact}

Analysis model 2 substructure equation which was formed individually, is: $\mathrm{Y}=19.81+0.22 * \mathrm{X} 1+0.52 * \mathrm{X} 2+0.18 * \mathrm{X} 3$, Errorvar $=0.34 \mathrm{Ry}=0.66$.

Substructure coefficient (1). R2 $=0.66$. The equation structure formed is said to be significant and can be used as a prediction tool to observe the signs, which occur towards variable $\mathrm{Z}$ caused by treatment, which is given, by $\mathrm{Y}, \mathrm{X} 1$, and X3.

Indirect Impact

$\mathrm{PX} 1-\mathrm{z}=(\mathrm{px} 1) .(\mathrm{pz}) . . \mathrm{X} 1$ towards $\mathrm{Z}$ through $\mathrm{Y}$

$$
=(0,22)(0,34) ; \mathrm{Px}_{1-\mathrm{z}}=0,748 \quad \mathrm{R}^{2} \mathrm{X}_{1-\mathrm{Z}}=0,66
$$

$=14,513$ Highly Significant

$\mathrm{pX} 2-\mathrm{Z}=(\mathrm{px} 2) \cdot(\mathrm{pz}) \ldots \mathrm{X}_{2}$ towards $\mathrm{Z}$ through $\mathrm{Y}$

$=(0,52)(0,34) ; \mathrm{p} 2-\mathrm{z}=0,1768 \mathrm{R} 2 \times 2-\mathrm{z}=0,66$

$=3,429$ Highly Significant

$\mathrm{pX} 3-\mathrm{Z}=(\mathrm{px} 3) \cdot(\mathrm{pz}) \ldots \mathrm{X} 3$ towards through $\mathrm{Y}$

$=(0,21)(0,34) ; \mathrm{p} 2-\mathrm{z}=0,714 \mathrm{R} 2 \mathrm{x} 2 \mathrm{z}=0,66$

$=13,851$ Highly Significant

Due the to the absence of a direct impact which connects variable $\mathrm{X} 2$ to $\mathrm{Z}$, therefore the total impact $\mathrm{Px} 2$ is equal to the coefficient score of the indirect impact from $\mathrm{X} 2$ to $\mathrm{Z}$.

Table 2. Summary of the Indirect Impact Coefficient

\begin{tabular}{|c|c|c|c|c|}
\hline \multirow{3}{*}{ variable } & \multicolumn{4}{|c|}{ Impact Indirect } \\
\hline & \multirow{2}{*}{$\mathrm{P}$} & \multirow{2}{*}{ t-count } & \multicolumn{2}{|c|}{ t-table } \\
\hline & & & $0.05^{*}$ & $0.01 * *$ \\
\hline $\mathrm{X} 1$ towards $\mathrm{Z}$ & 0,748 & 14,513 & \multirow{3}{*}{1.960} & \multirow{3}{*}{2.576} \\
\hline $\mathrm{X} 2$ towards $\mathrm{Z}$ & 0.177 & 3.429 & & \\
\hline X3 towards $\mathrm{z}$ & 0.714 & 13,851 & & \\
\hline
\end{tabular}




\section{Total Impact}

Based on the statistical test results of this research, there is a total impact $\mathrm{x} 1$ and $\mathrm{z}$ as much as $(\mathrm{Px} 1 \mathrm{y} \times \mathrm{Pyz})+(\mathrm{Px} 1 \mathrm{z})$ which is; $(0,22 * 0,34)+0,31=0,99 ;(2)$ total impact of $\mathrm{x} 2$ and $\mathrm{z}$ value $=(\mathrm{PYX} 2) *(\mathrm{PZY})=(0.52)+(0,34)=0,86 ;$ and the total impact of $\mathrm{x} 3$ and $\mathrm{z}$ value $=(\mathrm{Px} 3 \mathrm{y} * \mathrm{Pyz})+(\mathrm{Px} 3 \mathrm{z})=$ 0,92. The equation, which represents the impact, is as follow: $\mathrm{Y}=19.81+0.22 * \mathrm{X} 1+0.52 * \mathrm{X} 2+0.18 * \mathrm{X} 3$, Errorvar $=0.34$ $\mathrm{Ry}=0.66 \ldots . .(1) \mathrm{Z}=28.10+0.34 * \mathrm{Y}+0.31 * \mathrm{X} 1+0.21 * \mathrm{X} 3$, Errorvar. $=0.43$ Rý $=0.57 \ldots \ldots .(2)$

\section{DISCUSSION}

Implication Based conclusion above, this research will provide implication as: (1) if it will improve governance, it should be improve of leader quality, culture organization and empowerment in private collage, and (2) if it will improve quality of leader performance, it should be improve on governance, leadership and empowerment in private collage.

\section{Recommendation (Suggestions)}

A recommendation from an academically point of view is that there needs to be the addition of a variable, that variable being contingency, the use of another method of analysis, the creation of a mechanism to optimize managerial performance, the commitment of leaders in a leadership, the increase in organization culture which begins form the internal, and the empowerment of organization culture.

To cultivate values held by PRIVATE COLLLAGE to every human can be done by way of conveying the desired value in the language adopted by most employees. Narrative meaning according to the desired value based on the benefits in it perceived by its members. Encourage employees with positive statements about their ability to carry out shared values. By getting to know the culture of the organization, it will facilitate the management in taking both strategic and operational decisions.

Measures of performance and governance of the college should be clearly understood by all employees and involve all employees, especially ones regarding the association measures of organizational performance with the goal of managerial work program. Performance measurement should be accepted and trusted as a reference by those who are going to use it.

The identity of this study shows that leadership, organization culture, and empowerment of human resources on good governance towards managerial performance gives an impact (multiplier effect) towards satisfaction of employees and stakeholders in PRIVATE COLLLAGE is of moderate level. It has implications from improvement in stung organization culture through: 1) A resource strategy in the form of financial motivation and non financial motivation as well as positive and negative motivation in order to increase the competence and commitment of the employees, and 2) a business strategy in order to improve education services and institution income motivation through profit center: UPT university to be optimal. Thus affecting the managerial, organizational, stakeholders, and employee performance.

Local cultural needs to be adapted of characterized by their regional culture, nationally and globally to develop the quality of the environment which is more attractive to the users of educational services (think globally, act locally), so that there will be a change where today is better than yesterday, and tomorrow will be better than today. Periodically, for example once a year, the Department will need to evaluate the success, effectiveness, efficiency and benefits of empowerment activities of the lecturers as a whole. Chairman of the Department does not have to wait for the mandate from the Dean or the Rector to plan and carry out activities regarding faculty empowerment. Each lecturer should always seek to develop themselves in a sustainable manner within various fields of capabilities that can support the implementation of the department's mission. Leaders of the Department / Faculty / University coordinate, assist, support, facilitate, and / or provide facilities for lecturers who want to develop themselves. Leaders of the Department / Faculty / University need pioneering, seek and take advantage of various opportunities to empower lecturers.

Programs regarding the empowerment of lecturers which are planned well foster a culture which encourages lecturers to keep on improving which will eventually become a foundation for the success and reputation of the majors. The audit through Quality Assurance managerial performance in Private College is not yet maximized. Compared to other dimensions, evaluating the effectiveness is the highest followed by evaluation of the efficiency and economizing evaluation. Commitment to Organizations in Private College in the majority of leaders is not maximized.

The application of principles of good governance in Private Collage is not maximized. Fairness dimension occupies the highest-level followed accountability, transparency, and the lowest is independence. Managerial performance of Private College, which is not yet maximized, is directly impacted by leadership, application of the principles of good governance and empowerment.

The biggest impact in managerial performance of Private College not being maximied lies in the organizational culture and governance. Empirically, the condition of the internal culture which is not maximized yet in showing by the low reputation of PRIVATE COLLLAGE in which it is not included in the entry of World rank, not even Southeast ASIA.

\section{CONCLUSION}

Leadership has a positive significant impact towards managerial performance which shows that the bigger impact of leadership level, the higher level of managerial performance of leaders at Private College, South Sumatera. Organization culture has a direct impact towards good governance, which is indicated by means of the higher the impact of leadership is towards performance in Private College, therefore the higher the level of performance of leaders at Private College, South Sumatera. This is due to 
several elements in leadership, which is also present in managerial performance such as driving human resource, financial management, time management, and appraisal.

Empowerment has a direct impact towards good governance. This means that the bigger impact of leadership towards the level of leadership at Private Collage, therefore the better the level of managerial performance of the leaders at Private Collage in South Sumatera. This is because there are several elements in leadership which are also present in managerial performance such as driving human resources, financial management, time management, and appraisal. Leadership has a direct impact towards good governance $(p x 1 y=p y x 1)$ with a value of 0.656 and path coefficient value 0.22 . This shows that the better the higher impact of leadership towards managerial performance, the higher level of managerial performance of leaders at Private College in South Sumatera. This is because there are several elements in leadership which are also present in managerial performance such as driving human resources, financial management, time management, and appraisal.

Empowerment has a significant and positive impact towards managerial performance as much as 0.620 and a path coefficient Pzx3 value of 0.21 . This shows that the higher impact of Empowerment towards the level of managerial performance, the higher level of managerial performance for leaders at Private College in South Sumatera. This is because there are several elements in Empowerment which are also present in managerial performance such as driving human resources, financial management, time management, and appraisal.

Good governance has a direct impact on managerial performance as bid as 0.661 with a path coefficient value of 0.34. This shows that the better the higher impact of leadership is towards the level of good government, the better and higher the level of managerial performance of leaders of Private College at South Sumatera. This is because there are several elements in leadership which are also present in managerial performance such as driving human resources, financial management, time management, and appraisal.

Leadership has an indirect impact towards managerial performance through good governance with a value of 0.62 and a path coefficient value of 0.748 . This shows that the better and higher the impact of leadership is towards the leadership level, the better the managerial performance of leaders of Private College in South Sumatera. This is because there are several elements in leadership which are also present in managerial performance such as driving human resources, financial management, time management, and appraisal.

Organization culture has a significant and high indirect impact towards managerial performance through good governance with a value $=0.109$ and a path coefficient value of 0.1768 . This shows that the better the higher impact of organization culture towards the level of leadership is, the better level of managerial performance produced by Private College leaders in South Sumatera. Empowerment has a significant indirect impact, which is positive towards managerial performance through good governance with a value of 0.612 and a path coefficient value of 0.174 . This shows that the better impact of managerial performance towards the level of leadership, the better level of managerial performance produced by Private College leaders at South Sumatera. This is because there are several elements in leadership which are also present in managerial performance such as driving human resources, financial management, time management, and appraisal.

\section{REFERENCES}

[1] Antonio, Muhammad Syafii, 2007., Muhammad SAW the Super Leader Suver Manager. Jakarta:Prophetic leadership \& Management Centre.

[2] Artley, Will and Stroh, Suzanne., 2001, The Performance-Based Management Handbook: A Six - Volume Compilation of Techniques and Tools for Implementing the Government Performance and Resuts of 1993 (GPRA), Volume Two Establishing an Integrated Performance Measurement System.

[3] Al Rasyid, Harun 2001. Penarikan Sampel dan Penyusunan skala. Makalah Kuliah Program Pasca Sarjana, UNPAD, Bandung. Alhusin, Syahri,. Aplikasi Statistik Praktis dengan SPSS 10 For Windows: Yogyakarta Penerbit Graha Ilmu, 2002.

[4] As-Swaidan, Thariq M \& Basyarahil Faishal Umar. Melahirkan Pemimpin Masa Depan. Jakarta: Gema Insan, 2005.

[5] Andrew Podger., 2002, "Performance Management,": Commonwealth of Australia, Series Book List. Brownell, and McInnes. 1986. Budgetary Participation, Motivation, and Managerial Performance. The Accounting Review. pp. 587-600.

[6] Brownell, P. 1982. Participation in Budgeting Process: When it Works and when it doesn't. Journal of Accounting Literatur. pp. 124153.

[7] Cohen, J. And Cohen, N. 1993. Applied Multiple Regression/Corrrelation Analysis For The Behaviorall Sciences. Second Edition, Lawrencwe Erlbaum Association,USA.

[8] .Carnegie Mellon., "Performance Review Guidelines,"

[9] Dale McManis., 2000, "The Role of Comprehensive School Health Education Programs in the link Between Health and Academic Performance," : A Literature Review.

[10] Derek Rollinson, David Edwards, Aysen Broadfield., 1998, "Organizational Behaviour and Analysis,": An Integrated Approach, Addison - Wesley Longman.

[11] Dikti, Higher Education Long Term Strategy 2003- 2010

[12] Gosling, David., D'Andrea, Vaneeta., 2001, Quality Development: a new concept for higher education, Proceeding of The Sixth QHE Seminar.

[13] Giovanni Dosi, Patrick Llerena, Mauro Sylos Labini., 2005, "Eavaluating and Comparing the innovation performance of the United States and the European Union,":Expert report prepared for the TrendChart Policy Workshop, Jun.

[14] Gibson, Ivancevich \& Donnelly.1985., Organizations : Behavior, Structure, Processes. USA : Business Publications, Inc.

[15] Gibson, James L., Ivancevich, John M. \& Donnelly, James H. Organisasi, Perilaku Struktur, Proses (terjemahan Nunuk Ardiani). Jakarta : Binarupa Akasara, 1996.

[16] Gibson, James L., Ivancevich, John M. \& Donnelly, James H. Jr. Organizations.: Boston: McGrow-Hill, 2006. Greenberg,

[17] Jerald dan Baron, Robert A. Behavior in Organizations. New Jersey: Prentice Hall, 2003. Gilmore, Thomas N. 1997. Organizational learning and the leadership skill of time travel. Juurnal of Management Development, vol. 16 No. 41997.

[18] Kusnendi. Analisis Jalur: Konsep dan Aplikasi dengan Program SPSS dan Lisrel 8. Bandung : Badan Penerbit Jurusan Ekonomi UPI, Bandung, 2005.

[19] Kreitner, Robert and Kinicki, Angelo. "Organizational Behavior". New York, Both of Arizona State University, 2007. Hughes, Richard L., Robert Crdon J. Leadership: Enhancing the Lesson of Experience. New York: McGraw - Hill, 2002. 
[20] Ivancevih, John, M., Donnelly, James H., Gibson, James L. Manajement:Principles and Funtions. India : Richard D. Irwin , Inc, 2003.

[21] Ivancevih, John, M., Robert Konopaske, and Michael T. Matteson. Organizational Behavior and Management. New York: McGraw-Hill Companies, Inc., 2008. Kartono, Kartini, 1992., Pemimpin dan Kepemimpinan Jakarta: Rajawali Pers.

[22] John Maynard Keynes., "Marketing: investment advisor to the businesss; The performance manager series COGNOS An IBM COMPANY

[23] Juran, Joseph M. Dalam Tjiptono, Fandiy \& Diana, Anastasia. Total Quality Management. Yogyakarta: Andi, 2003.

[24] Kerlinger, Freed N. Asas-asas Penelitian Behavioral. Yogyakarta: Gadjah Mada University Press, 1990.

[25] Mahoney, T. A., T. H. Jerdee, and S. J. Carrol. 1963. Development of Managerial Performance: A. Research Approach. Cincinnati, OH: South western publising company.

[26] Mangunegara, A.A. Anwar Prabu, 2000. Manajemen Sumber Daya Manusia. Bandung. PT. Remaja Rosdakarya.

[27] Marshall Mcluhan., "Information Technology: a pathfinder tobetter performance; The performance manager series COGNOS An IBM COMPANY.

[28] Nawawi, H. Hadari. 2006., Kepemimpinan Mengefektifkan Organisasi. Yogyakarta: Gajah Mada University Press.

[29] LAtchem, Colin., Parker, Lesley., 1995, Developing a Teaching and Learning Strategic Plan : A Case Study, Proceeding of HERDSA '95 annual conference, UCQ, Rockampton.

[30] Luthans, Pred. Organization Behavior, Eleventh Edition, Boston; in Organization McGRAW.HILL, 2008.

[31] Sarwono, Jonathan. Analisis Jalur Untuk Riset Bisnis dengan SPSS: Yogyakarata : Penerbit Andi Offset, 2006.

[32] Tampubolon, P. Daulat., 2001, Paradigma Baru Manajemen Pendidikan Tinggi Bermutu Menghadapi Tantangan Abad ke-21, Penerbit PT Gramedia Pustaka Utama Jakarta.

[33] Tohmas Brailsford., "Human Resources: manajemen or administration of human capital; The performance manager series COGNOS An IBM COMPANY.

[34] Peter Jarvis, 2001, "Universities and Corporate Universities,": The Higher Learning Industry in Global Society, KOGAN PAGE.

[35] .Pedomana Penulisan Tesis \& Disertasi:Jakarta Penerbit Program Pascasarjana, 2007. Website :http//www.ppsunj.org.

[36]_.Performance Management Guidelines, Sectin July, 1991.

[37] Salusu, J., 1996, Pengambilan Keputusan Stratejikk.Roberts, Jakarta : PT. Gramedia Widiasarana Indonesia. , 1996.

[38] Siagian, Sondan, P., 2002. Kiat Meningkatkan Produktivitas Kerja.Jakarta: PT. Rineka Cipta. Schein, H., Edgar. "An Organizational Culture and leadership".(San Fransisco: Yossey Bass Publisher. 1992 Schein, Edgar. Organizational Culture and leadership”. San Fransisco: JohnWiley \& Son, 2004.

[39] Schermerhon, John R., Hunt, James G. Jr., and Osborn, Richard N. Managing Organizational Behavior New York:.JohnWiley and Sons, 1995.

[40] Silalahi, Ulber. "Metode Penelitian Sosial," Bandung: Refika Aditama, 2009.

[41] Sugiyono, 2006, Metode Penelitian Kuantitatif, Kualitatif dan R \& D, Penerbit Alfabeta Bandung, Cetakan kesatu.

[42] Sulistyani. A. T. (Editor), 2004. Memahami Good Governance dalam Perspektif Sumberdaya Manusia. Penerbit Gava Media. Yogyakarta Stoner, James A. F., R. Edward Freeman, Daniel R. Gilbert, Jr., Management, Englewood Cliffs, New Jersey: Prentice Hall, 1992.

[43] Roberts, Carole., Anderson, Lisa., Betts, Martin., Oakey, Dorotho., 2002, Developing a Supportive Culture for Teaching and Learning: A University, Faculty and School Perspective, http://

[44] Robbins, Stephen P. Essentials A. Judge. Orgazation Behavior. New Jersey: Person Educations, Inc, Upper River, 2007.

Originalitas penelitian:

[45] Robbins, Stephen P., and Timothy Essentials Of Orgazation Behavior. New Jersey: Pentice Hall, 2000.
[46] Riduwan dan Engkos,Achmad Kuncoro. Cara menggunakan dan memaknai Analisis Jalur (Path Analisis) : Badan penerbit ALFABETA, Bandung 40153, 2008

[47] _2005,University of California Higher Education Compact Performance Measures.

[48] _.2004,Strategi Jangka Panjang Pendidikan Tinggi 2003-2010 (HELTS): Meningkatkan peran serta masyarakat., Departemen Pendidikan Nasional Republik Indonesia Direktorat Jenderal Pendidikan Tinggi.

[49] Wahr, Fiona., Radloff Alex., 2002, Using quality assurance to drive a teaching and learning agenda :Taking a risk, meeting the challenge., Proceeding of HERDSA, 2002.

[50] Ward, Janet., Lee, Cheryl L., 2004, Teaching Strategies for FCS: Student Achievement in Problem-Based Learning Versus LectureBased Instruction, Journal of Family and Consumer Services, page 73, Januari 2004 Vol 96 No 1, USA.

[51] Wibisono,Dermawan.,2006.,"Manajem en Kinerja,": Konsep, Desain, dan Teknik Meningkatkan Daya Saing Perusahaan, Penerbit Erlangga Ciracas, Jakarta 13740. e-mail :editorerlangga. net (Anggota IKAPI).

[52] Wibowo. Manajemen Kinerja. Jakarta : PT Raja Grafindo Persada, 2007. Yulk, Gary."Leadership Organization. Upper Sadddle River, New Jersey: Person Prentice- Hall, 2006. 